\title{
Contribuições de Deleuze e Guattari para as pesquisas em educação ${ }^{1}$
}

\author{
Sandra Mara Corazza
}

\section{I - O ensaio é isso}

Em O Abecedário de Gilles Deleuze (1), no vocábulo Professor, Claire Parnet pergunta a Deleuze (então, com 64 anos e aposentado) se ele não sentia falta de dar aulas, já que as dera, com paixão, durante quase quarenta anos, no ensino médio e no superior. Deleuze responde-Ihe que, no momento, é uma alegria não ter mais de dar aulas, porque já não tinha mais vontade; embora elas tivessem constituído uma parte importante da sua vida. Diz, então, que essa questão das aulas é simples, já que elas têm equivalentes em outras áreas, em função de ser algo muito preparado: - "Se você quer 5, 10 minutos de inspiração, tem de fazer uma longa preparação". E acrescenta que sempre fez desta maneira porque gostava: - "Eu me preparava muito para ter esses poucos momentos de inspiração". Entretanto, com o passar dos anos, começou a perceber que precisava "de uma preparação crescentemente maior para obter uma inspiração cada vez menor". E concluiu que estava na hora de parar, para fazer outra coisa, como escrever. Ele diz que não saberia calcular quanto tempo essas preparações lhe exigiam, mas que, como tudo, tratava-se de ensaios: - "Uma aula é ensaiada, como no teatro". Se não a ensaiarmos suficientemente, "não estaremos inspirados", e se ela não resultar de "momentos de inspiração", não quererá "dizer nada". O ensaio que fornece a inspiração consiste em "considerar fascinante a matéria da qual tratamos", em achar "interessante o que se está dizendo", para "chegar ao ponto de falar de algo com entusiasmo". E Deleuze finaliza: - "O ensaio é isso".

Para ensaiar Deleuze, ao escrever sobre algumas ressonâncias de scripturire provocadas por sua filosofia da diferença na Educação, vários usos conceituais poderiam ser enfatizados, tais como os que vêm sendo produzidos em vários espaços institucionais, de relações e textuais (2). Seguindo Barthes (3), podemos dizer que, para que as escolhas que fazemos dos conceitos (textos, livros, obras) dos outros passem para nós, é necessário que os definamos como escritos por nós.

\footnotetext{
${ }^{1}$ Uma versão modificada desse texto foi, primeiramente, publicada na Revista Educação, da USP de São Paulo, com o título "Para pensar, pesquisar e artistar a educação: sem ensaio não há inspiração", em 2007, p.68-73.

2 Professora do Departamento de Ensino e Currículo e do Programa de Pós Graduação em Educação da Faced, UFRGS. Líder do grupo de Pesquisa DIF e Pesquisadora de Produtividade 1 do CNPq.
} 
E que, ao mesmo tempo, os tornemos outros, deformando-os por amor, desde que por eles fomos seduzidos. O que buscamos, nos conceitos que desejamos, é que alguma coisa ocorra: uma nova aventura, uma nova conjunção amorosa; e, por isto, a relação que estabelecemos com determinados conceitos do autor amado é que eles ficam lá, como signos de nós próprios, inspirando-nos a passar do Prazer de Ler ao Desejo de Escrever (Scripturire = Querer-Escrever).

É em nome dessa relação, que distingo, nesta Conferência: A) primeiramente, seis conceitos deleuzianos, que são os de 1 . cartografia, 2 . impessoalidade, 3. simulacro, 4. devir, 5. nômade e 6. acontecimento; B) em segundo lugar, com eles realizo uma antropofagia; $C$ ) para, em terceiro, responder à questão $O$ que Deleuze quer da Educação?, por meio de quatro temáticas, quais sejam: $1^{a}$ ) criançascartógrafas-impessoais em devir-artista; $2^{\mathrm{a}}$ ) professores-pedagogos-educadores em devir-simulacro; $3^{a}$ ) currículos-nômades; $4^{a}$ ) pesquisa do acontecimento.

\section{II - O que Deleuze quer da Educação?}

Quem vem por lá, no meio da neblina? Quem entra sem bater, sem se anunciar, sem dizer o nome próprio? Quem chega ao jardim de infância da Educação? As crianças assustam-se, pois, vêem, é um homem de saúde frágil, a quem freqüentemente falta ar. Elas gritam por socorro, ao olharem suas unhas longas, não aparadas, que protegem a falta de impressões digitais. Todos se perguntam: O que ele vem fazer aqui? O que quer da Educação? Cometerá violências contra a sua educação, ao fazê-las aprender a pensar sem imagens e a desaprender o que já aprenderam? Quem ele acha que é, para vir se meter com elas, até agora tranqüilamente fixadas em formas essenciais e saturadas por definições substanciais? Quanto atrevimento por parte de quem nunca atribuiu à infância qualquer valor, enquanto fonte do sujeito, origem do sentir e do pensar adultos! Quanta invasão de quem jamais deu qualquer importância à infância-arquivo, à criança-lembrança ou ao infantil-universal, por privilegiar somente um devircriança do mundo! Que ousadia a desse homem intrometer-se na Educação, justamente ele que, enquanto aluno, foi uma nulidade na escola... (Até descobrir que a filosofia podia ser tão desafiadora e divertida quanto qualquer obra de arte!)

Os professores tentam acalmar as crianças, mas elas choram de medo, quando o homem Ihes fala com sua voz rouca e dicção fatigada, como as de um feiticeiro. Então, mostram-lhes que este pensador traz, para todos, belas, novas e fortes lufadas de enunciação, que nos levam a pensar e a viver a Educação do mesmo modo que um artista pensa e vive a sua arte. Explicam-Ihes que se trata de um 
filósofo que prossegue a tarefa (que Spinoza começou e Nietzsche continuou) de nos levar a detestar todos os poderes ligados à tristeza, os quais transmitem a ideia de vivermos em estado perpétuo de dívida infinita. De alguém que tem horror a tudo que apequena e entristece a vida, isto é, dos poderes de quem trabalha para diminuir ou nos separar das forças ativas de que somos capazes; e que, com isso, buscam conduzir nossas vidas à resignação, à má-consciência, à culpa, recheandoas de afetos tristes e imobilizadores, de queixas e de ressentimentos.

As crianças, agora, entendem melhor o rico presente que esse homem trouxe consigo: a possibilidade de pensar e de viver a alegria em Educação. Já que ele mostra como amar tudo aquilo que desenvolve e efetua as potências afirmativas e como odiar todos os poderes que obstaculizam essa efetuação. E Ihes diz que qualquer poder é sempre muito triste, mesmo se aqueles que o exercem alegramse ao fazê-lo: - Os que exercem os poderes e com eles se alegram são uns pobres coitados, porque a sua é uma alegria triste! Neste momento, as crianças param de chorar. Porque se existem, neste Universo, criaturas que não querem saber de alegrias tristes, mas só de alegrias que as regozijam, por serem o que são e por chegarem aonde chegam, por meio de suas potências infantis, essas criaturas são as crianças! No entanto, os professores alertam: - Sejam prudentes! Não exibam demasiadamente essa alegria em estado puro, pois há muita gente para quem a infantilidade - que diz um Sim incondicional à Vida - é insuportável!

\section{III - Cartógrafas-impessoais-artistas}

Após o pavor que o encontro inicial com o Feiticeiro do Pensamento da Diferença provocara, tudo muda na Educação. A começar pelas próprias crianças, que não mais se pensam nem são pensadas como embriões originários do ser humano cognitivo e psíquico nem como fontes da sociedade e da cultura. Mas que se anunciam como cartógrafas, impessoais e artistas. Cartógrafas, porque exploram os meios (das aulas, escolas, parques), fazem trajetos dinâmicos pelas vizinhanças (das ruas, campos, animais), traçam mapas virtuais (dos currículos, projetos político-pedagógicos), em extensão e intensão, que remetem uns aos outros, e que elas superpõem aos mapas reais, cujos percursos, então, são transformados. Como mapeadoras extensivas dos movimentos das relações pedagógicas de poder e dos deslocamentos de saberes curriculares, as crianças redistribuem impasses e aberturas desse poder, limiares e clausuras desses saberes, limites e superações dos seus modos de subjetivação, em busca do Acontecimento - que elas sabem não se tratar de fatos educacionais, dados históricos, práticas pedagógicas, embora ele não exista fora dessas efetuações, só que, nelas e em seu existir atual, o 
Acontecimento não se esgota, porque é imaterial, incorporal e virtual. Como mapeadoras intensivas de afetos (ativos e alegres, passivos e tristes), as crianças produzem constelações educacionais que preenchem suas deambulações sociais. Impessoais, falam e escrevem por indefinidos, já que estes consistem na forma de expressão que precede as manifestações da subjetividade infantil, e que faz das crianças singularidades pré-individuais e consciências pré-reflexivas sem Eus. Elas adoram o indefinido uma-criança, que é como se enunciam como sensíveis, o que as leva à conclusão de que também são Artistas, já que fazem as mesmas coisas que a Arte. Ou seja, as crianças Cartógrafas-Impessoais e a Arte: 1. não ordenam lugares, mas abrem rasgões para o Fora; 2. movimentam-se sobre um devirinfantil e sobre o esquecimento da história e o abandono das lembranças de infância; 3. percorrem passagens e linhas erráticas de materiais flexíveis e heteróclitos; 4 . desenroscam anéis de superfície pura sem interior nem exterior; 5. conectam e desconectam inimagináveis zonas de vizinhança; 6. jogam pedras numa velocidade infinita contra todos os organismos; 7. realizam viagens históricomundiais sem saírem do Continente da Infância e da Arte; 8. abrem e fecham portas, telhados e planos, enlouquecendo totalmente o pensamento do bom senso da Infância e do senso comum da Arte. Em suma, em devir-infantil, as crianças, cartógrafas, impessoais e artistas fazem até voar os morcegos que bicam as suas janelas.

\section{IV - Devir-simulacro}

- Estivemos sempre sob o jugo do Princípio de Identidade. Este é um diagnóstico que Deleuze realiza (juntamente com toda filosofia pós-nietzschiana), e que orienta o seu pensamento em direção oposta ao da identidade - a qual, para reunir a multiplicidade sob um conceito deve, necessariamente, igualar o não-igual. Assim, ao utilizar esse Princípio da Identidade para formular a designação uniformemente válida do conceito de Professor, abandonamos todas as diferenças singulares das inúmeras maneiras de ser, de tornar-se, de operar como um professor, além de despertar o pensamento da Representação.

Pois, esse Princípio, ao formular o conceito de Professor, nos leva a esquecer tudo aquilo que é distintivo como se, no campo da Educação, além dos vários professores e de suas ações individualizadas e desiguais, houvesse algo ou alguém que fosse O Professor-Primordial (Uno, Padrão, Verdadeiro, Normal), a partir do qual todos os professores fossem formados, embora por mãos inábeis; de modo que nenhum saísse correto e fidedigno à Ideia Pura daquele Professor-Modelo, dotado de uma qualidade essencial, ou qualitas occulta, cujo nome pode ser Professoralidade, e à qual cada um e todos os professores deverão submeter-se ou 
se esforçarem para dela se aproximarem, como Cópias bem ou mal assemelhadas; ou, em caso contrário, serão considerados simulacros, os quais, por estarem tão distantes e por serem tão dessemelhantes da Professoralidade (que é a causa de $O$ Professor e de todos os professores), serão profundamente desprezados.

Tal matriz platônica compõe o que Deleuze denomina Imagem Dogmática de Pensamento que integra a Filosofia da Representação; a qual, junto a todas as áreas que operam com o pensamento monocentrista, positiva as Cópias-Ícones, como sucedâneos válidos do Original, enquanto teme os simulacros (fantasmes), considerados estranhos, primitivos, selvagens, desviados, divergentes e perigosos subversivos das hierarquias estabelecidas - casos perdidos, que Platão detestava e recomendava que fossem jogados nos abismos dos oceanos mais profundos ou abandonados no mais recôndito das florestas -, já que negam tanto o Original quanto as Cópias.

Filosofia da Representação que, em Educação, valoriza positivamente os Professores-Cópias (como imitações do Primordial), já que eles têm relações diretas com a Ideia Pura da Professoralidade e são, assim, os seus pretendentes bem fundados; ao mesmo tempo, em que desvaloriza os professores-simulacros, como falsos pretendentes, que sobrevivem graças a semelhanças falsificadas, porque, em verdade, vivem abertos para a dessemelhança e, desse modo, ficam cada vez mais afastados do centro do Modelo-Ideia-Essência-de-O-Professor.

Vê-se, facilmente, como uma filosofia dessas somente pode ser formulada num plano transcendente, concebido como um além-mundo superior, organizado, ordenado e, claro, hierarquizado; num plano metafísico, que preexiste e sobreexiste àquele plano ordinário no qual os professores vivem e atuam; num plano idealista, que amaldiçoa a diferença, ao desconsiderá-la por meio do conceito, já que cada professor, como Cópia-Ícone, deve representar, reapresentar o Modelo, e, desta maneira, repetir o seu agir, fazer, dizer, pensar, sentir. Assim, quando um professor é denominado como Bom, Verdadeiro, Correto, Competente, e um outro professor é denominado como Mau, Falso, Incorreto, Incompetente, é porque cada um está sendo julgado por sua Professoralidade, em função do maior ou menor grau de semelhança ou de infidelidade a ela, considerada a causa de todos eles.

Já a Filosofia da Diferença (também chamada por Deleuze de Empirismo Transcendental) reverte esse plano transcendente e privilegia a mobilidade 
perpétua do real, exercida num plano da imanência, o qual deve ser traçado pelos professores, que the vão dando consistência à medida que o criam por meio de experimentações. Plano, que é deste mundo dos professores, e no qual o único serprofessor que pode ser dito é o do devir, isto é, daquele ser que não pára nunca de se deter no jogo da sua própria proliferação. Plano, que é povoado por professores em devir-simulacro, que tira a força da sua imanência dos conceitos nietzschianos de Vontade de Potência e de Eterno Retorno, que não repetem o Mesmo, mas que, a cada repetição, produzem a Diferença Pura. Por isto, é que o platonismo, em Educação inclusive, é ferido de morte, em sua diferença relativa - entre O-BomProfessor e O-Mau-Professor, que nada mais são do que Cópias, bem ou mal assemelhadas ao Padrão -, a qual sempre hierarquiza, ao privilegiar uns e secundarizar outros. Platonismo ferido pelo pensamento deleuziano, que valoriza justamente os professores-simulacros, como os únicos que têm possibilidades de produzir novidades e de levarem a Educação à diferença não maldita, já que só eles possuem forças inventivas orientadas para o por vir.

Esse devir-simulacro dos educadores-professores-pedagogos pode ser chamado, também, de Gaia Ciência, porque fornece ferramentas conceituais para pensar um devir-alegre, um devir-criador, um devir-artista, num plano educacional de imanência. Plano, no qual a aula brilhante que um professor, porventura, tenha dado, hoje, não será comparada a nenhum Modelo-de-Aula, nem às outras aulas dadas por ele ou por seus colegas; tampouco terá ele sido um Bom-Professor, em comparação com um Professor-Padrão, nem com outros professores; mas, porque, hoje, circunstancialmente, ele conseguiu formular algo novo para pensar; ele problematizou, com e diante dos alunos, o que até então não era considerado problemático por ninguém; ele fez os alunos desaprenderem as besteiras-verdades, que Ihes tinham sido ensinadas e que eles assimilaram, para, assim, poderem aprender algo que não fosse senso comum nem opinião; ele conseguiu mostrar que a dificuldade de pensar é algo de direito do pensamento, já que pensar não tem nada de inato, nem de recognição, nem se trata de responder perguntas para as quais já existem respostas, nem de pensar a partir de postulados previamente definidos; mas, pensar é criar e, portanto, trata-se de engendrar o pensar no próprio pensamento: condição de possibilidade para uma criação que merece este nome dado por um Pensamento sem Imagem.

Um pensamento que os professores em devir-simulacro podem experienciar, pois é relativo à economia de fluxos materiais e semióticos do desejo (nem subjetivo nem representativo), que precedem sujeitos e objetos, procedem por afetos e 
transformações, independentemente de serem ou não calcados sobre pessoas, imagens, identificações. Desse modo, um professor etiquetado como Tradicional, um pedagogo rotulado como Construtivista e um educador definido como Progressista podem ser atravessados por devires múltiplos: por um devir-simulacro que coexiste com um devir-mulher, com um devir-criança, com um devir-animal, com um devir-negro, com um devir-poético, com um devir-imperceptível.

Essa ideia do devir-simulacro liga-se a processos de singularização e remete à problemática da multiplicidade. Processos e problemática que excluem a obsessão que o Pensamento da Representação instalou, no campo educacional, de encontrar, formular ou reconhecer algum perfil, identidade, função, papel de O Professor, os quais reificam, de forma pétrea, uma natureza pedagógica verdadeira, uma essência universal de professor, uma arcaica vocação educadora, um modo certo de planejar, de dar aula, de avaliar. Tal devir-simulacro é composto por processos transversais de artistagem, que permeiam as diferentes subjetividades dos educadores, instauram-se através de cada um deles e dos grupos sociais, realizando uma crítica radical a essas formas determinadas e funções legitimadas.

Devir-simulacro de pedagogos-artistas, feito por elementos virtuais embora reais, que se distinguem apenas pelo movimento e pelo repouso, pela lentidão e pela velocidade; que não são átomos embora sejam finitos; que, embora dotados de formas, nem por isso são indefinidamente divisíveis; e que consistem nas últimas partes, infinitamente pequenas de um infinito atual, estendidas num plano de consistência. Partes que se definem pelos graus de intensidade e pelas relações nos quais entram, e que pertencem a este ou àquele professor, pedagogo, educador, artista, que pode ser parte de outro, numa relação complexa, embora cada um seja uma multiplicidade de multiplicidades perfeitamente individuada.

Os educadores-artistas são tomados em segmentos de devir-simulacro, cujas fibras levam deste devir a outros, transformam estes devires naquele, atravessam limiares de poderes, saberes, subjetividades. Desse modo, quando os professoresartistas compõem, pintam, estudam, escrevem, pesquisam, ensinam, eles têm apenas um único objetivo: desencadear devires. Devires que são sempre moleculares, já que devir não é imitar algo, nem identificar-se com alguém, tampouco promover relações formais entre identidades. A partir da bagagem cultural que esses pedagogos-artistas possuem, de suas formas-professorais, do sujeito-educador em que se transformaram, das funções-educativas que aprenderam a exercer, devir-simulacro é extrair partículas disso tudo, que são as 
mais próximas daquilo que eles estão em vias de se tornarem, e através das quais tornam-se outros educadores, professores, pedagogos e artistas diferentes do que são.

Assim, devir-simulacro é o próprio processo do desejo de educar. Isto é, a partir do educador que ele é, dos fundamentos, metodologias, pedagogias que aprendeu, de como ele sabe exercer a sua profissão, o professor-artista entra na zona de vizinhança - que marca a pertença a uma mesma molécula, independentemente dos sujeitos e das formas - do desejo, ou em sua co-presença, entre as partículas extraídas do que ele carrega em si, e que não mais pertencem ao que ele é, ao que ele possui, a como ensina. Por isso, um pedagogo-educador-professor em devirartista-simulacro é considerado uma hecceidade, isto é, uma coletividade molecular, não separável de um espaço corpuscular. Não que um professor se torne um artista, ou que um pedagogo se assemelhe a um artista, ou que um educador seja análogo a um artista, ou vice-versa, já que o devir não é metáfora simbólica; e sim que o educador, o professor, o pedagogo e o artista invocam uma zona objetiva de indeterminação ou de incerteza, comum e indiscernível, na qual não se pode dizer onde passam as fronteiras de uns e de outros.

E não pensem que esse devir-simulacro acontece somente para alguns privilegiados, corajosos ou iluminados! Todos os educadores, pedagogos, professores e artistas, independentemente de evoluções, possuem lugar para outras possibilidades inatuais e para outros devires. Devires que não são regressões, mas involuções criadoras, núpcias antinatureza, que ocorrem fora dos corpos programados e dão testemunho de uma vivificação permanente. Essa é a realidade do devir-artista dos educadores-simulacros e do devir-educador dos artistas-simulacros, sem que os educadores tornem-se artistas ou os artistas tornem-se educadores. Porque no devir-simulacro, não se compara e, quando se usa a palavra como, esta já mudou de sentido e de função, porque ficou remetida às hecceidades, em vez de a sujeitos significados ou a estados significantes.

Assim, quando um professor brinca, um educador uiva, um pedagogo canta, um artista ensina, se isso for feito com bastante intensidade e paixão, o professor emite uma criança molecular; o educador, um lobo molecular; o pedagogo, um cantor molecular; o artista, um professor molecular. Não que um se torne o outro, como se mudassem de espécies molares, em suas formas e subjetividades; o que ocorre é uma emissão de partículas, que entram em vizinhança com moléculas compostas, e que produzem um professor-criança, um educador-lobo, um 
pedagogo-cantor, um artista-educador moleculares. Claro que é no professor que a criança brinca, no educador que o lobo uiva, no pedagogo que o cantor canta, no artista que o pedagogo-educador-professor ensina, mas por emissões corpusculares, e não por imitação nem pela proporcionalidade de suas formas. Assim, como mudam também a realidade-em-devir da criança, do lobo, do cantor, do artista, sem que eles se tornem professores, educadores ou pedagogos.

\section{V - Currículos-nômades}

Desde a chegada do pensamento de Deleuze na Educação, vê-se como - para crianças-cartógrafas-impessoais em devir-artista e para professores-pedagogoseducadores-artistas em devir-simulacro - já não é mais possível operar com qualquer tipo de currículo; a não ser com currículos plurais, que podemos chamar por diferentes nomes, como Currículos-Nômades, e que apresentam os seguintes componentes em seu plano de composição.

Sem memória nem ambição, disforme e alienado, fora de si, esse Currículo-Louco é ilegítimo, odeia planos homogêneos e unidades metodológicas, objetivos e projetos, formas didáticas e medidas avaliativas. Pensado a partir de um desmoronamento da interioridade do pensamento curricular, é dotado da potência extrínseca de surgir em qualquer ponto e de traçar qualquer linha, irrompendo nas águas mansas da sabedoria adquirida, de modo involuntário, imprevisto, incompreensível, inassimilável. Vive às voltas com as forças do Fora, como uma violência que se abate destrutiva sobre os saberes consolidados, como um estranhamento recíproco entre o pensamento racional e a realidade de algum objeto. Por se movimentar em outro espaço-tempo, esse Currículo-Errante é inconstante, versátil, anda de terra em terra, corre mundo, de modo que os seus pontos se alternam, subordinados aos trajetos que eles mesmos vão traçando, enquanto seus traços apagam-se à medida que os trajetos vão sendo feitos. Em movimento perpétuo, com vagos trejeitos de um Currículo-Ambulante, distribui-se, em espaços abertos, sem partilha, sem alvo nem destino, sem partida nem chegada, crescendo no meio do campo curricular como grama.

Currículo-Fluido, desterritorializa e reterritorializa, faz ruptura das próprias territorialidades, abrindo-se para o novo e consolidando-o, mediante a construção de outras adjacências, desfaz-se e renuncia a si mesmo, vai embora para outra parte. E, mesmo que os fluxos desse Currículo-Turbilhão sejam canalizados por condutos e diques, precipita-se, torna a jorrar, transborda, flexibilizando as distinções binárias, ternárias e sintéticas, afetando seus pontos heterogêneos, 
fazendo com que se revezem, ramifiquem-se e se encadeiem, extrinsecamente, para se tornarem vetores de transformação. Polimorfo e difuso, bifurcado e fibrilado, esse Currículo-Estrategista corre solto numa atmosfera de errâncias. Deformante e móvel, esse Currículo-Ubíquo agencia elementos díspares, opera multiplicidades acentradas, realiza disjunções inclusivas e, por meio de sua rapidez e leveza, conecta-se com outras máquinas de pensar e de viver que têm forças vivas de devires, para conjurar o peso e a gravidade de currículos paquidérmicos e tingidos de cinza-chumbo.

Currículo-Imoderado, fornece provas de interações inéditas com crianças, professores, matérias, vivendo cada instante curricular molar, em termos de relações moleculares e de movimentos de fuga. Por ser um Currículo-Amoroso com aquilo que inventa, conjura as cruéis forças econômicas e políticas, as insuportáveis humilhações humanas, os centros de poder, desenrolando seus segmentos e figuras imóveis e dispersando-os, de modo que voltem a bailar. Currículo-Dançarino, que não pretende ter desenvolvimento autônomo ou tomar algum poder e, inclusive, espanta-se com a servidão abjeta dos Currículos-Oficializados, não entendendo como eles podem ser tão desejados, triunfantes e duradouros. Irritado com os torpores, adaptações e consciências dos Oficializados, esse Currículo-Abalo tensiona-os, faz com eles piruetas e cambalhotas, dá-lhes rasteiras com novas ideias, cria personagens misteriosos, que são irrepetíveis.

Indisciplinado, esse Currículo-Rebelde questiona conservações e convenções, regimes de legitimidade e roubalheira, direções constantes e delimitações fincadas sobre codificações. Currículo-Bandido, define-se por suas ações livres, inventa revides, luta, joga projéteis, questiona hierarquias, regimes de propriedade, direções constantes, delimitações de objetos, e se transforma em arma para ferir os currículos firmados sobre bases sólidas. Não releva sentimentos ternos diante de nenhum sujeito dos Currículos-Equilibrados, embora seja pleno de afetos variáveis, que atravessam corpos de alunos e de professores como flechas, numa velocidade infinita de desterritorialização andeja. Possuidor de uma Ciência-Menor, contrária à Ciência-Régia, esse Currículo-Balístico reporta-se a agenciamentos maquínicos e a agenciamentos coletivos de enunciação, definindo-se pelo conjunto das singularidades extraídas de seus fluxos curriculares, que convergem para uma consistência inventiva.

Currículo-Hiper-Ativo, funciona como uma máquina vagamunda, social e coletiva, cujos agenciamentos definem, num determinado e volátil momento, a sua 
racionalidade curricular e o seu nível de compreensão, quais os usos e a extensão dos seus conteúdos, as paixões e os desejos das suas emoções de Currículo-Eros, o qual promove descargas de afetos múltiplos, opostos aos pesados conhecimentos estáveis, bagagens culturais, valores eternos, sujeitos idênticos, essências constantes, verdades verdadeiras. Um Currículo-Itinerante desses pode ser chamado de Currículo-Mar, pois é fluência pura, nada representa, não fixa lugares, não disciplina, mas engendra-se e percorre-se, faz fugir os sujeitos e os objetos os quais implicam um ponto de vista fixo e exterior, procedem por iteração, valorizam reiterações, reconhecem fenômenos, buscam resultados, comprovam constantes. Já um Currículo-Intuitivo capta as singularidades da matéria e a variação contínua das variáveis para constituir a sua territorialidade móvel. Remetido ao par matéria e forças, subordina suas operações às condições sensíveis da intuição e da construção, por isso, é tanto arte quanto técnica, produz mudanças de estado, processos de deformação e de transformação dos modelos, métodos e programas gradeados, opera individuações por acontecimentos e por hecceidades, nunca por fatos ou por sujeitos.

Como um Currículo-Anexato, não deixa de ser rigoroso, pois, não é nem inexato como as coisas sensíveis, nem exato como as essências ideais, possuindo essências vagas - que despreendem uma materialidade não confundível com a essencialidade inteligível ou com a coisidade sensível -, as quais geram uma identidade anexata entre os pensamentos e as coisas curriculares. Materialidade de um CurrículoForça, cujas matéria-movimento, matéria-energia e matéria-em-variação são seguidas por uma intuição em ato, que não pára de situar-se de um lado e de outro de seus limiares, nem de transformar as matérias homogeneizadas e as formas estabelecidas.

Esse Currículo-Problemático antes formula problemas do que os resolve. Por isto, é um Currículo-Aprendizado, a operar como experiência de problematização, que não fornece condições empíricas do saber, não faz transição do saber ao não-saber, não é solução para alguma falta de saber. Currículo-Aprendente, não sabe direito como alguém aprende; só sabe que não é por assimilação de conteúdos, nem por faculdades inatas, ideias a priori, elementos transcendentes. Ao juntar o pensar, o aprender e o viver, procura tornar o pensamento possível outra vez, pois acredita que, assim, pode retirar o pensar de sua imobilidade e de sua separação da vida. Encontrando-se em relação com forças e velocidades infinitas do caos, é um Currículo-que-aprende-ao-mesmo-tempo-em-que-ensina, a partir da questão $O$ 
que é pensar? - que só acontece na imanência absoluta, na criação de novidades e na vida ativa.

Currículo-Vitalista, dotado de vida com luz própria e produtividade híbrida, rizomática, dá saltos, faz desembocaduras, passagens, desvios, que costumam ser sobrecodificados pelo pensamento curricular reativo e triste, que os tenta capturar, sitiar e harmonizar, de modo a colmatar suas fugas, subordinar suas diferenças às identidades, impor limites a suas inumeráveis conexões. Por isso, é um CurrículoInimigo da adequação do intelecto às coisas, do amigável acordo entre as faculdades mentais, do Bem/Mal, do Certo/Errado, do Verdadeiro/Falso. Currículode-Briga com o pensamento moral, besteiras comunicativas, opinião medíocre, contemplação, reflexão, clichês, decalques, regras, ordens, certezas fáceis e repetidas ad nausean. Currículo-Violento, cuja violência chega-lhe do não conhecido, do tempo não cronológico de Aion, dos elementos selvagens não domesticados, ou seja, do Fora, que Ihe é trazido pelos Signos. Signos que fazem dele um Currículo-Enigma, pois forçam-no a pensá-los, a decifrá-los, a interpretálos; para que, assim, ele possa praticar um ensinar e um aprender imprevisíveis, que nos levam a não reconhecer nada do que até então conhecíamos, impedemnos de pensar e de viver como antes, e nos constrangem a desprendermo-nos de nós mesmos.

Esse Currículo-Ignorante ensina que importa perder tempo para aprender e para enamorar-se dos Signos, de sua necessidade e urgência, inevitabilidade e força. Currículo-Aventureiro, não propõe gestos a serem reproduzidos ou conteúdos a serem reconhecidos, nunca diz - Faça como eu faço!, mas convida: - Venha, faça comigo! Encadeando sensibilidade, intuição e pensamento para sacrificar os Imperativos dos Objetos, as Palavras de Ordem da Linguagem e a Facilidade das Recognições, funciona como um atrator-caótico, contagiando e propagando, puxando, arrastando matérias e encontros para um devir-vagamundo, feito da proliferação de possíveis e da ramificação de não-sensos. E é tão forte esse Currículo-Desejante, que só se preocupa em ser avaliado pelo que produz e pelos efeitos que causa: são importantes e interessantes, notáveis e potencializadores de mais vida? Esse Currículo-Ladrão-da-Paz não adota jamais uma posição neutra ou passiva diante do mundo e da vida; ao contrário, trata-os como uma questão de artistagem, vinculada à produção de diferenças, a intervenções e à invenção de vidas ricamente vividas por minorias ex-cêntricas, que procedem por difusões móveis de prestígio. 
Por sua própria natureza, esse Currículo-Gangue existe e opera, mesmo que de modo imperceptível, em Todos os Currículos Existentes e em Funcionamento. Embora os Currículos-Oficializados queiram sempre pô-lo na prisão, segmentarizar seus espaços lisos, cortar suas linhas de fuga, represar seus fluxos que teimam em escorrer. O problema é que os Currículos-Bandos movimentam os Oficializados porque estes (embora muita gente não aceite ou não perceba) vivem em metamorfose perpétua e em errância perigosa, voam, galopam, varrem tudo aquilo que, neles, foi organizado e ordenado, enquanto dualidades, correspondências, estruturas; de modo a poderem criar novos movimentos curriculares que ousem impulsos inovadores e vivam em permanentes devires-revolucionários.

Agora, chegou a hora: - Como criar para si um Currículo-Clandestino que desenvolva, no campo curricular, um novo espaço de pensar? Como abrir nossos poros e criar novas sensibilidades, que nos dêem condições de possibilidades para acompanhar os movimentos imperceptíveis e intempestivos de currículos fortemente codificados? Ora, é simples: - Fiquemos atentos! Porque esses Currículos-Andarilhos fazendo aparições descontínuas, praticando atos violentos, esticando linhas de inovação, criando contra-pensamentos para pensar o impensável, o não-pensado do pensamento, a exterioridade pura, acabam movimentando todos os currículos, sem exceção. Então, cabe a um pedagogoprofessor-educador em devir-simulacro, que trabalha com crianças-cartógrafasimpessoais em devir-artista, analisar as multiplicidades não métricas e os pontos de singularidades de cada um dos Currículos-Codificados, para ver do que eles ainda são capazes, quais são as suas vagas, andamentos curvilíneos, o turbilhonar de suas linhas diferenciais e os novelos de seus fios subterrâneos, que saem de um Currículo-Malta arrastam um Codificado e o explodem.

Então, nesse campo de batalha desordenado, nesse vapor incorporal de pura intensidade, nessa cena funerária do sujeito, nesse espelho cego dos objetos, nessa película de experimentação rebelde, nesse tabuleiro de jogo ideal, nessa dobradiça do aprender, nesse reservatório do pensar, em um tempo fora dos gonzos, renascendo e recriando-nos, altiva e revolucionariamente, viveremos, com prazer e gozo, a porção Marginal dos Currículos-Certinhos. Porção que são como grandes fetos mexendo-se, boiando, mergulhando, circulando e crescendo na barriga do grande Tubarão Pensamental do Currículo-Maior. Engendrar, encontrar e seguir ou não esses fetos, cuidar ou não deles, é uma questão de juventude ou de velhice, de tristeza ou de alegria, de vida ou de morte. É aí que a covardia ou a coragem de cada um de nós se decide. 


\section{VI - Pesquisa do Acontecimento}

Por último, na relação amorosa com os conceitos deleuzianos, distingo um deles que me parece imprescindível para a pesquisa contemporânea em Educação: o de Acontecimento. Conceito formulado ao longo de toda a produção de Deleuze: desde a sua Tese de Estado Diferença e repetição - na qual, tanto o problema quanto suas condições são remetidos à ordem do Acontecimento; até ganhar força e complexidade em Lógica do sentido - sob influência da teoria estóica dos incorporais (4) e de Leibniz; passando pelo livro A dobra. Leibniz e o Barroco - em que há um capítulo inteiro dedicado à questão "Que é um acontecimento", e no qual Whitehead é identificado como o terceiro pensador do Acontecimento; indo até o último livro escrito com Guattari $O$ que é a filosofia? - em que aparecem como influências Péguy e Blanchot, saudados como os novos pensadores que foram capazes de penetrar o Acontecimento; chegando até o seu último texto "A imanência: uma vida...", em que escreve: "Uma vida (...) é feita de virtualidades, acontecimentos, singularidades. Os acontecimentos ou singularidades dão ao plano toda sua virtualidade, como o plano de imanência dá aos acontecimentos virtuais uma realidade plena. $\mathrm{O}$ acontecimento considerado não-atualizado (indefinido) não carece de nada".

\section{VII - Como pode acontecer um Pensar-Ensinar, um Pesquisar- Criticar, um Ler-Escrever, um Diferir-Artistar na Educação de hoje?}

De uma Pesquisa do Acontecimento (5), seguem-se novas maneiras de pensar e de realizar uma crítica-escrileitura, que vão até a singularidade da experimentação de cada pesquisador-professor, num processo de artistagem inventiva da Educação. Por essa via, buscam-se novas formas de expressão e de conteúdos, as quais derivam de percursos intensivos e trajetos extensivos das produções que vêm sendo realizadas, já há alguns anos, no campo educacional; lutas contra a secura dos corações, a acídia nas relações e o agreste dos códigos; inspirações fornecidas por filósofos, escritores, educadores do Pensamento da Diferença, os quais participam de um gesto coletivo, cuja divisa consiste na palavra simples de Nietzsche, embora dotada de um poder infinito: - "Uma nova maneira de sentir, uma nova maneira de pensar" (6); esse gesto coletivo fornecedor de impulsos para que também a Educação participe da "pesquisa de novos meios de expressão", que Deleuze aponta para a Filosofia, em Diferença e repetição: "Aproxima-se o tempo 
em que já não será possível escrever um livro de Filosofia como há muito tempo se faz: 'Ah! O velho estilo...' A pesquisa de novos meios de expressão filosófica foi inaugurada por Nietzsche e deve prosseguir, hoje, relacionada à renovação de outras artes, como, por exemplo, o teatro ou o cinema"; uma Educação, portanto, a ser criticada, lida e escrita, enquanto "ficção científica", no sentido em que não se evita "aquilo que não sabemos ou que sabemos mal", mas que é realizada, necessariamente, "neste ponto que imaginamos ter algo a dizer"; já que dar um jeito de acabar com a ignorância faria com que transferíssemos, indefinidamente, "a escrita para depois" ou a tornaríamos impossível. Assim, para a Pesquisa do Acontecimento, escrever não é impor uma forma de expressão a uma matéria vivida, mas trata-se de um procedimento informe, de um processo inacabado, de uma passagem de Vida que atravessa o vivível e o vivido. E, quando o professorpesquisador critica-lê-escreve, fica comprometido com a Literatura do Acontecimento, necessitando ser um bom artesão, um esteta, um pesquisador de palavras, frases, imagens, para atuar no limite, na "ponta extrema" que separa o saber e a ignorância, e os transforma.

Por ser construída ao mesmo tempo em que se desenvolve, esta Pesquisa possui uma natureza empírica-transcendental e condensa, nas ações correlatas de pensar, criticar, ler e escrever, que Ihes são constitutivas, a criação de sentidos imanentes, que resultam duma reversão das representações feitas por outras pesquisas. Age despojada de qualquer significação prévia, pois se forma na anulação dos referentes externos e nos sentidos transcendentes anteriormente construídos. Seus movimentos são expressivos, em relação aos sujeitos, objetos, temáticas, já que não consiste num ato subjetivo decorrente de condições empíricas negativas, como a ignorância do pesquisador, nem objetiva ultrapassar obstáculos de desconhecimento acerca de algum fenômeno, como se pesquisar fosse uma passagem do não-saber ao saber. Ao contrário, trata-se de uma Pesquisa que investiga o "conhecimento" (7), no sentido deleuziano, como aquilo que não é "nem uma forma, nem uma força, mas uma 'função'". Conhecimento-função que não se realiza sobre "paradigmas arborizados do cérebro", mas é feito com "figuras rizomáticas, sistemas acentrados, redes de autômatos finitos, estados caóides", que se conjugam em processos criadores sobre planos de pensamento.

A Pesquisa do Acontecimento esparrama-se, assim, sobre três "planos", "disciplinas", "pedagogias" e respectivos componentes, que são como solos, nos quais ela se movimenta: a filosofia - com o seu plano de imanência, forma do conceito, conceitos e personagens conceituais; a arte - com o seu plano de 
composição, força da sensação, sensações e figuras estéticas; a ciência - com o seu plano de referência ou de coordenação, função do conhecimento, funções e observadores parciais. Ela pode operar, em separado, sobre cada um desses planos e utilizar seus elementos específicos; pode, também, dedicar-se às interferências intrínsecas de um plano sobre o outro e aos deslizamentos entre funções, sensações, figuras estéticas; ou pode, ainda, efetivar-se sobre interferências ilocalizáveis, isto é, sobre os negativos de cada disciplina, pois, a ciência encontrase em relação com uma não-ciência; a filosofia necessita de uma compreensão não-filosófica; e a arte precisa da não-arte - "em cada instante de seu devir ou de seu desenvolvimento". A sua energia provém, assim, da utilização de múltiplas linguagens (ciência, pintura, música, literatura, cinema, poesia), que the fornecem a consistência de uma coexistência heteróclita, a qual transforma os elementos pesquisados numa unidade virtual, à medida que cria um vazio na consciência atual que deles possuímos.

Dedicando-se à parte não-histórica do que acontece em Educação, esta Pesquisa trata os conceitos como acontecimentos e não como noções gerais, como singularidades e não como universais; o que não implica reconversão filosófica ao aqui-e-agora, nem troca do essencial pelo acidental, já que o Acontecimento a ser pesquisado é um dinamismo criador - que permaneceria imperceptível se tentasse ser investigado pelos canais habituais da tradição. Buscando o Acontecimento, a Pesquisa substitui a questão ontológica da Essência "O que é"? pelas questões da novela, do conto, do romance "O que se passou"? "O que vai se passar"? (8). Experimentando e mostrando o Acontecimento, como produção de eventos, a Pesquisa troca o eterno pelo presente, não realizando uma fenomenologia da atualidade, mas uma "Ontologia do Presente", no sentido de Foucault (9). Assim, ela não pesquisa divisões, unidades, identidades definidas e formadas (crianças, professores, currículos), mas as diagramatiza em fuga, valoriza seus devires, nomadismos e inatualidades, conceitualizando suas configurações por vir.

Para tal Pesquisa, tudo é considerado Acontecimento puro, isto é, potencialidade inexistente fora de suas atualizações e, todavia, delas transbordante. Incorporal sem ser vago, coletivo e particular, perceptível e microscópico, o Acontecimento é modo de individuação, ligado a um clima, a um clarão, a um silêncio, a outros acontecimentos. Ele não designa coisas, fatos, ações, paixões dos corpos, estados de ser, pessoas, sujeitos porque os toma como individuados por linhas acontecimentais, como individuações assubjetivas, impessoais, subpessoais, cada 
qual com duração própria e variável, embora intensiva, feita de afetos e de sensações.

Relatórios, críticas, leituras, escrituras desta Pesquisa do Acontecimento são constantemente dissolvidos e reformulados por novos planos de pensamento, os quais procuram identificar a imagem peculiar de cada linguagem, afastar o nevoeiro de universalidade que rodeia cada pedagogia, restabelecer 0 momento da originalidade de cada pensar. A Pesquisa investe, portanto, contra tudo aquilo ao qual o pensamento se dirige: a besteira, o erro, a superstição, a ideologia, a estupidez, o senso comum, o bom senso, a opinião, a comunicação. Para escapar da "Imagem Dogmática do Pensamento", ela posiciona-se a favor de que pesquisar é criar e criar é problematizar; só que problematizar é determinar dados e incógnitas dos problemas, que vão sendo formulados à medida que a pesquisa se realiza e que persistem nas soluções que the são atribuídas, como num jogo afirmativo de novidades, por meio da Vontade de Pesquisar. Vontade que, para o professor-pesquisador, abre novos caminhos, os quais interferem e ecoam uns nos outros, graças a materiais de expressão ainda informes ou de conteúdos incodificados.

Pesquisa que se dedica a raspar, escovar, lixar clichês de resultados já organizados, para construir um espaço liso, como no Deserto, onde seja possível realizar experiências transcendentais. Pesquisa desenvolvida, por meio de imagens e de signos, que a burilam esteticamente e dela fazem um compósito de afectos e de perceptos. Pesquisa que atenta, a um só tempo, para as multiplicidades das multiplicidades e para os seus movimentos de desterritorialização, reterritorialização, territorialização. Pesquisa que, ao traçar mapas de intensão e de extensão, considera, em primeiro lugar, as linhas de fuga; depois, as moleculares, mais flexíveis; e toma as linhas duras, molares, como resíduos secundários; pois refere decalques aos mapas, relaciona raízes e árvores aos rizomas, e nunca o inverso. Pesquisa que investiga os agenciamentos em suas duas faces: a do agenciamento técnico-maquínico, voltada para os estratos; a do agenciamento coletivo de enunciação, voltada para o corpo sem órgãos.

Amante dos encontros, a cada vez em que é exercida, esta Pesquisa estabelece diferentes relações entre os elementos e compõe geografias inéditas, nos quais os acontecimentos se tecem e destecem, já que não há, para ela, primeiros princípios, representações eternas, regras normativas, orientações naturais. Assim, os professores pesquisam incessantemente porque não acreditam nas coisas da 
Educação e detestam a inércia pedagógica que os impele a repetir. Eles possuem como guias iniciáticos suas paixões concretas, que os desviam dos conjuntos espaço-temporais, não os deixam passar ao longo do Acontecimento, nem recolher a sua efetuação na atualidade; mas os levam a instalarem-se no Acontecimento, como num devir, para fazerem rejuvenescer e envelhecer, simultaneamente, todos os componentes e singularidades que na Educação circulam. Então, os pesquisadores-professores conseguem criar algo novo, ao promoverem a irrupção de um devir em estado puro, que Nietzsche chamou "Intempestivo" ou "Inatual". Pesquisa-Intempestiva de uma Educação-Inatual, que implica que os Pesquisadores sejam dignos do Acontecimento e que os Professores artistem a Educação - tudo isso em devir-revolucionário. Único devir que conjura o intolerável e nos faz voltar a acreditar no mundo.

\section{Ideias-força. Referências. Bibliografia.}

(1) O Abecedário de Gilles Deleuze in http://www.oestrangeiro.net/

(2) Vide Dossiês "Deleuze e a Educação" de Educação \& Realidade e "Entre Deleuze e a Educação" de Educação e Sociedade; além de teses de doutorado e dissertações de mestrado realizadas, dentre outros, nos seguintes programas de Pós-Graduação do Brasil: 1) em Educação da Faculdade de Educação da UFRGS, na Linha de Pesquisa Filosofia da Diferença e Educação, orientados por Paola Zordan, Sandra Corazza e Tomaz Tadeu; 2) em Educação do Centro de Educação e Humanidades da UERJ, na Linha de Pesquisa Infância, Educação e Filosofia, orientados por Walter Omar Kohan; 3) em Educação da Faculdade de Educação da UNICAMP, na Área de Concentração Filosofia e História da Educação, orientados por Sílvio Donizetti de Oliveira Gallo; 4) em Psicologia Social e Institucional do Instituto de Psicologia da UfRGS, na Linha de Pesquisa Clínica, Subjetividade e Política, orientados por Rosane Neves da Silva e Tânia Maria Galli Fonseca; 5) em Educação da Faculdade de Educação da USP, na Área de Concentração Psicologia e Educação, orientados por Julio Groppa Aquino, como a Tese de Doutorado de Sandra Cristina Gorni Benedetti, intitulada "Entre a educação e o plano de pensamento de Deleuze \& Guattari: uma vida..."

(3) Roland Barthes. A preparação do romance I: da vida à obra. São Paulo: Martins Fontes, 2005. [Trad. Leyla Perrone-Moisés.]

(4) Émile Bréhier. La théorie des incorporels dans l'ancien stoïcisme. Paris: J.Vrin, 1997.

(5) Vide: 1) Projeto de Pesquisa Pós-currículo, diferença e subjetivação de infantis, No Processo 301451/01-0, CNPq, 2005-2007; 2) "Pesquisar o 
Acontecimento: estudo em XII exemplos" in Tomaz Tadeu; Sandra Corazza; Paola Zordan. Linhas de escrita. Belo Horizonte: Autêntica, 2004 (p.7-p.78).

(6) Friedrich W. Nietzsche. Assim falou Zaratustra. Um livro para todos e para ninguém. São Paulo: Círculo do Livro, 1986. [Trad. Mário da Silva.]

(7) Gilles Deleuze; Félix Guattari. Qu'est-ce que la philosophie? Paris: Minuit, 1991. [O que é a filosofia? Rio de Janeiro: Ed.34, 1992. Trad. Bento Prado Jr. e Alberto Alonso Muñoz.]

(8) Gilles Deleuze; Félix Guattari. "8. 1874 - Trois nouvelles, ou 'qu'est-ce qui s'est passé?" in _. Capitalisme et schizophrénie 2. Mille plateaux. Paris: Minuit, 2004 (p.235-242). ["Platô 8. 1874 - Três novelas ou 'o que se passou" in _.. Mil platôs: capitalismo e esquizofrenia. Rio de Janeiro: Ed.34, 1996, vol.3. Trad. Ana Lúcia de Oliveira e Lúcia Cláudia Leão. (p.63-p.81).]

(9) Gilles Deleuze. Foucault. Paris: Minuit, 1991. [Foucault. São Paulo: Brasiliense, 1988. Trad. Claudia Sant'Anna Martins.] 